\title{
ANALISIS FAKTOR-FAKTOR YANG MEMPENGARUHI PREDIKSI PERINGKAT OBLIGASI
}

\author{
Wydia Andry ${ }^{1}$
}

\begin{abstract}
A bstract
The current paper analyze the prediction of the obligation rating and how they are ditermined. Unlike the previous studies, we include both the accounting and the non-accounting factors, and test the explanatory power of the following six variables: (1) the growth, (2) the size (3) the sinking fund, (4) the risk (with or without guarantee), (5) the maturity structure and, (6) the auditor's judgement.

The data consists of the bank and the financial firms listed in Jakarta Stock Exchange and Surabaya Stock Exchange. As the endogenous variable is discrete, we apply the probit regression model on the data and test how the six exogenous variable above can influence the rating of obligation. The results indicates that in general, the obligation of Indonesian firms are investment grade. The study also conform the significance of the growth, the sinking fund, the maturity and the auditor, while the size and the risk are both insignificant to predict the rating of obligation.
\end{abstract}

Key words: Rating obligation, growth, size, sinking fund, risk, maturity, logif regression.

JEL Classification: E43, E44, G11

1 Penulis adalah konsultan pada Tim ASKI DPNP, Bank Indonesia. wydia_andry@yahoo.com. 


\section{PENDAHULUAN}

Obligasi adalah surat berharga atau sertifikat yang berisi kontrak antara pemberi pinjaman (investor) dengan yang diberi pinjaman (emiten). Seorang pemodal yang berminat membeli obligasi, sudah seharusnya memperhatikan peringkat obligasi. Peringkat obligasi merupakan skala risiko dari semua obligasi yang diperdagangkan. Peringkat obligasi ini penting karena peringkat tersebut memberikan pernyataan yang informatif dan memberikan signal tentang probabilitas kegagalan utang suatu perusahaan (Maylia 2004).

Agen pemeringkat obligasi adalah lembaga independen yang memberi informasi pemeringkatan skala risiko utang, salah satu diantaranya adalah sekuritas obligasi, sebagai petunjuk seberapa aman suatu obligasi bagi investor. Keamanan ini ditunjukkan oleh kemampuannya dalam membayar bunga dan melunasi pokok pinjaman. Pemodal bisa menggunakan jasa agen pemeringkat obligasi tersebut untuk mendapatkan informasi mengenai peringkat obligasi. Di Indonesia terdapat dua lembaga pemeringkat sekuritas utang, yaitu PT PEFINDO (Pemeringkat Efek Indonesia) dan PT Kasnic Credit Rating Indonesia (Rahardjo, 2003). Penelitian mengenai obligasi masih jarang dilakukan di Indonesia terutama mengenai penggabungan kemampuan faktor-faktor akuntansi dan non akuntansi dalam memprediksi peringkat obligasi. Padahal akhir-akhir ini penerbitan obligasi mulai semarak dan mulai banyak obligasi perusahaan yang secara konsisten terdaftar dalam peringkat obligasi perusahaan yang dikeluarkan oleh agen PEFINDO.

Pemilihan variabel-variabel yang diduga dapat mempengaruhi peringkat obligasi mengacu pada beberapa model penelitian terdahulu. Beberapa penelitian sebelumnya menggunakan faktor akuntansi yaitu rasio keuangan yang berasal dari neraca, cash flow dan laba rugi diantaranya: Horrigan (1966); Pinches \& Mingo (1973; 1975); Kaplan \& Urwitz (1979); Chan \& Jagadeesh (2003); Nurhasanah (2003) dan Kesumawati (2003), Maylia (2004). Peneliti termotivasi melakukan penelitian karena menurut Burton et al. (1998) growth/ pertumbuhan perusahaan. juga merupakan faktor akuntansi yang mempengaruhi prediksi peringkat obligasi, disamping itu Pottier dan Sommer (1999) juga menyatakan size (ukuran perusahaan juga dapat mempengaruhi prediksi peringkat obligasi. Kedua faktor akuntansi ini belum pernah diteliti di Indonesia, kemudian selain faktor-faktor akuntansi, faktor-faktor non akuntansi seperti risiko yang dipengaruhi oleh keberadaan dan kualitas jaminan (collateral), sinking fund (Foster, 1986), dan maturity (Diamond, 1994) serta auditor (Allen, 1994) juga bisa mempengaruhi prediksi peringkat obligasi juga belum pernah diteliti. Penelitian ini berbeda dengan penelitian-penelitian di Indonesia, penelitian ini berusaha melihat faktor-faktor akuntansi dan non akuntansi yang mempengaruhi prediksi peringkat obligasi di Indonesia. 


\section{TINJAUAN LITERATUR DAN PENGEMBANGAN HIPOTESIS}

\section{II.1 Obligasi}

Obligasi adalah surat utang jangka panjang yang dapat dipindahtangankan yang berisi janji dari pihak yang menerbitkan untuk membayar imbalan berupa bunga pada periode tertentu dan melunasi pokok utang pada waktu yang telah ditentukan kepada kepada pihak pembeli obligasi tersebut (Bursa Efek Surabaya, 2001).

Emisi obligasi dapat ditinjau dari dua sisi, yaitu dari emiten maupun dari sisi investornya (Warsono 1997). Dari sisi emitennya, emisi obligasi merupakan salah satu altenatif pendanaan yang relatif lebih murah dibandingkan dengan pinjaman ataupun kredit bank. Dari sisi investornya, emisi obligasi merupakan alternatif investasi yang aman. Karena obligasi memberikan penghasilan tetap berupa kupon bunga yang dibayar secara reguler dengan tingkat bunga yang kompetitif serta pokok utang yang dibayar secara tepat waktu pada saat jatuh tempo yang telah ditentukan.

\section{II.2 Pemeringkat Obligasi}

Seorang pemodal yang tertarik untuk membeli obligasi tentunya harus memperhatikan rating obligasi (bond ratings). Ratings atau peringkat, merupakan sebuah pernyataan tentang keadaan pengutang dan kemungkinan apa yang bisa dan akan dilakukan sehubungan dengan utang yang dimiliki, sehingga dapat dikatakan bahwa rating mencoba mengukur resiko default, yaitu peluang emiten atau peminjam akan mengalami kondisi tidak mampu memenuhi kewajiban keuangannya (Foster, 1986). Peringkat obligasi perusahaan diharapkan dapat memberikan petunjuk bagi investor tentang kualitas investasi obligasi yang mereka minati.

Pemodal bisa menggunakan jasa credit rating agency yang memberikan jasa penilaian terhadap obligasi yang beredar untuk mendapatkan informasi mengenai rating obligasi. Di Indonesia terdapat lembaga pemeringkat sekuritas utang yaitu PEFINDO (Pemeringkat Efek Indonesia).

Hasil dari pemeringkatan surat utang didasarkan atas beberapa hal seperti:

- Kemungkinan pelunasan pembayaran yaitu kemampuan obligor untuk memenuhi kewajiban financialnya sesuai dengan perjanjian.

- Struktur, karakteristik serta berbagai ketentuan yang diatur dalam surat utang.

- Perlindungan yang diberikan maupun posisi klaim dari pemegang surat utang tersebut bila terjadi pembubaran/likuidasi serta hukum lainnya yang mempengaruhi hak kreditur.

Tabel V.1a dan V.1b berikut ini menjelaskan mengenai fungsi dan definisi peringkat obligasi 


\begin{tabular}{|c|c|}
\hline \multicolumn{2}{|r|}{$\begin{array}{c}\text { Tabel V.1a } \\
\text { Definisi Peringkat PT PEFINDO }\end{array}$} \\
\hline Simbol & Arti \\
\hline AAA & $\begin{array}{l}\text { Efek utang yang peringkatnya paling tinggi dan beresiko paling rendah yang didukung oleh } \\
\text { kemampuan obligor yang superior relatif dibanding entitas Indonesia lainnya untuk memenuhi } \\
\text { kewajiban jangka panjangnya sesuai dengan perjanjian. }\end{array}$ \\
\hline AA & $\begin{array}{l}\text { Efek utang yang memiliki kualitas kredit sedikit dibawah peringkat tertinggi, didukung oleh } \\
\text { kemampuan obligor yang sangat kuat untuk memenuhi kewajiban financial jangka panjangnya } \\
\text { sesuai dengan perjanjian, relatif dibanding dengan entitas Indonesia lainnya. Dan tidak mudah } \\
\text { dipengaruhi oleh perubahan keadaan. }\end{array}$ \\
\hline A & $\begin{array}{l}\text { Efek utang yang beresiko investasi rendah dan memiliki kemampuan dukungan obligor yang } \\
\text { kuat dibanding entitas Indonesia lainnya untuk memenuhi kewajiban financialnya sesuai dengan } \\
\text { perjanjian namun cukup peka terhadap perubahan yang merugikan. }\end{array}$ \\
\hline BBB & $\begin{array}{l}\text { Efek utang yang beresiko investasi cukup rendah didukung oleh kemampuan obligor yang } \\
\text { memadai, relatif dibanding entitas Indonesia lainnya untuk memenuhi kewajiban financialnya } \\
\text { sesuai dengan perjanjian namun kemampuan tersebut dapat diperlemah oleh perubahan keadaan } \\
\text { bisnis dan perekonomian yang merugikan. }\end{array}$ \\
\hline BB & $\begin{array}{l}\text { Efek utang yang menunjukkan dukungan kemampuan obligor yang agak lemah relatif dibanding } \\
\text { entitas Indonesia lainnya untuk memenuhi kewajiban financial jangka panjangnya sesuai dengan } \\
\text { perjanjian serta peka terhadap keadaan bisnis dan perekonomian yang tidak menentu dan merugikan. }\end{array}$ \\
\hline B & $\begin{array}{l}\text { Efek utang yang menunjukkan parameter perlindungan yang sangat lemah. Walaupun obligor } \\
\text { masih memiliki kemampuan untuk memenuhi kewajiban financial jangka panjangnya, namun } \\
\text { adanya perubahan keadaan bisnis dan perekonomian yang merugikan akan memperburuk } \\
\text { kemampuan tersebut untuk memenuhi kewajiban financialnya. }\end{array}$ \\
\hline $\mathrm{CCC}$ & $\begin{array}{l}\text { Efek utang yang tidak mampu lagi memenuhi kewajiban financialnya serta hanya bergantung } \\
\text { kepada perbaikan keadaan eksternal. }\end{array}$ \\
\hline $\mathrm{D}$ & Efek utang yang macet atau emitennya sudah berhenti berusaha. \\
\hline
\end{tabular}

\section{II.3 Pengembangan Hipotesis}

Penelitian terdahulu menunjukkan berbagai kemampuan rasio keuangan sebagai alat prediksi yang memadai. Kemampuan prediksi rasio keuangan diukur dengan alat prediksi statistik yang dihubungkan dengan berbagai fenomena ekonomi, diantaranya kebangkrutan (Altman, 1968), kegagalan (Beaver (1966) dan Deakin (1972), penentuan kredit jangka panjang (Horrigan, 1966), serta return saham (Ou dan Penman (1989), dalam Machfoedz (1994).

Sejumlah penelitian yang meneliti prediksi peringkat obligasi berhasil dikumpulkan, namun penelitian serupa dengan mengambil kondisi pasar modal Indonesia sulit ditemukan. Hasil prediksi peringkat obligasi dengan menggunakan rasio keuangan ditemukan berbeda-beda oleh beberapa peneliti. Selain itu terdapat pula beberapa penelitian terdahulu mengenai variabel 
Tabel V.1b

Fungsi Dari Pemeringkat Obligasi

Enam fungsi dari pemeringkat utang perusahaan adalah (Foster, 1986) :

1. Sumber informasi superior atas kemampuan perusahaan atau pemerintah untuk membuat ketepatan waktu pembayaran kembali hutang pokok dan tingkat bunga yang dipinjamkan. Superioritas ini timbul dari kemampuan untuk menganalisis informasi umum atau mengakses informasi rahasia.

2. Sumber dengan biaya rendah bagi keluasan informasi kredit, terkait cross section antar perusahaan, pemerintah daerah dan pemerintah. Pengumpulan informasi tentang sejumlah perusahaan swasta, perusahaan pemerintah atau pemerintah daerah dapat sangat mahal. Hal ini akan lebih efektif jika informasi tersebut didapat dari suatu agen yang mengumpulkan, memproses, dan menyimpulkan informasi tersebut dengan mudah (dalam bentuk skala rating point).

3. Sumber "legal insurance" untuk pengawas investasi. Membatasi investasi sekuritas hutang hanya pada tingkat kategori yang tinggi saja.

4. Sumber sertifikasi tambahan terhadap hutang perusahaan ditetapkan, hal tersebut merupakan reputasi berupa resiko. Peringkat merupakan insentif bagi perusahaan yang bersangkutan, mengenai kelengkapan atau ketetapan waktu dari laporan keuangan dan data yang mendasari peringkat lainnya. Perusahaan peringkat dapat menyajikan sertifikat kualitas informasi yang diberikan oleh issuer atas sekuritas hutang yang diberikan peringkat.

5. Monitor terhadap kegiatan manajemen.

6. Memudahkan kebijakan publik yang melarang investasi spekulatif oleh institusi, seperti: bank, perusahaan asuransi dan dana pensiun.

non akuntansi.Tabel V.2 berikut (Maylia 2004) menunjukkan rangkuman perbandingan beberapa penelitian terdahulu yang menjadi acuan pemilihan variabel independen yang mampu memprediksi rating obligasi perusahaan manufaktur di Indonesia

\begin{tabular}{|c|c|c|c|}
\hline \multicolumn{4}{|c|}{$\begin{array}{c}\text { Tabel V.2 } \\
\text { (Ringkasan Penelitian Terdahulu) }\end{array}$} \\
\hline PENELITI & VARIABEL INDEPENDEN & TIPE ANALISIS & VARIABEL INDEPENDEN TERBAIK \\
\hline $\begin{array}{l}\text { HORRIGAN } \\
(1966)\end{array}$ & Rasio keuangan + subordination & Multiple Regression & $\begin{array}{l}\text { Subordination;TA; WCI/sales; net worth/TL, } \\
\text { sales/ net worth; and net operating profits/sales. }\end{array}$ \\
\hline $\begin{array}{l}\text { POGUE \& } \\
\text { SOLDOFSKY } \\
(1969)\end{array}$ & Rasio keuangan & Regresi & $\begin{array}{l}\text { Debt/TA, net income/TA, coefficient of variation } \\
\text { of net income/TA, } T A \text {, net income + interest/ } \\
\text { interest. }\end{array}$ \\
\hline WEST (1970) & Data non akuntansi & Regresi & $\begin{array}{l}\text { Earning variability; period of solvency; equity/ } \\
\text { debt ratio; bonds outstanding. }\end{array}$ \\
\hline $\begin{array}{l}\text { PINCHES \& } \\
\text { MINGO (1975) }\end{array}$ & Rasio keuangan + subordination & $\begin{array}{l}\text { Linear discriminant } \\
\text { function (MDA) }\end{array}$ & $\begin{array}{l}\text { Subordination; assue size; net income + interest/ } \\
\text { interest; years of consecutive dividends; LTLTA; } \\
\text { net income/TA. }\end{array}$ \\
\hline $\begin{array}{l}\text { ALTMAN \& KETZ } \\
\text { (1979) }\end{array}$ & Rasio keuangan & $\begin{array}{l}\text { Quadratic } \\
\text { discriminant } \\
\text { function }\end{array}$ & $\begin{array}{l}\text { Interest coverage, standard error of interest } \\
\text { coverage, cash flow. }\end{array}$ \\
\hline
\end{tabular}




\begin{tabular}{|c|c|c|c|}
\hline \multicolumn{4}{|c|}{$\begin{array}{c}\text { Tabel V.2 } \\
\text { (Ringkasan Penelitian Terdahulu (lanjutan)) }\end{array}$} \\
\hline PENELITI & VARIABEL INDEPENDEN & TIPE ANALISIS & VARIABEL INDEPENDEN TERBAIK \\
\hline $\begin{array}{l}\text { KAPLAN \& } \\
\text { URWITZ (1979) }\end{array}$ & Rasio keuangan & $\begin{array}{l}\text { Ordinary Least } \\
\text { squares regression } \\
\text { analysis (OLS) }\end{array}$ & $\begin{array}{l}\text { Subordination status; size; earnings stability; } \\
\text { leverage; earning coverage of interest, dan } \\
\text { profitabilitas. }\end{array}$ \\
\hline BELKAOUI (1983) & Rasio keuangan & \begin{tabular}{l|} 
Linear multiple \\
discriminant analysis
\end{tabular} & $\begin{array}{l}\text { TA; TL; STL/total modal investasi; CACL; fixed } \\
\text { change coverage ratio; cash flow lima tahun; } \\
\text { harga saham/EPS dan subordination. }\end{array}$ \\
\hline $\begin{array}{l}\text { GENTRY, } \\
\text { WHITFORD \& } \\
\text { NEWBOLD (1988) }\end{array}$ & Rasio keuangan \& funds flow & Probit model & $\begin{array}{l}\text { Inventori; other current liabilities; dividends; dan } \\
\text { fixed coverage charges; LTL/TA; net income/TA. }\end{array}$ \\
\hline $\begin{array}{l}\text { KETZ \& MAHER } \\
\text { (1990) }\end{array}$ & Asset flow & \begin{tabular}{|l|} 
Multiple \\
discriminant analysis
\end{tabular} & $\begin{array}{l}\text { Operating net income, operating net income }+ \\
\text { dep; WC from operation; cash flow from } \\
\text { operation. }\end{array}$ \\
\hline $\begin{array}{l}\text { BURTON, ADAMS } \\
\text { \& HARDWICK } \\
\text { (1998) }\end{array}$ & Rasio keuangan & $\begin{array}{l}\text { Ordered probit } \\
\text { model }\end{array}$ & Leverage; profitability; liquidity; firm size. \\
\hline $\begin{array}{l}\text { CHAN, JAGADEESH } \\
\& \text { WARGA (1999) }\end{array}$ & Rasio keuangan & $\begin{array}{l}\text { MDA, MDA cross } \\
\text { validation procedure, } \\
\text { oerdered probit } \\
\text { (Probit), and Probit } \\
\text { with stepwise } \\
\text { variabel selection } \\
\text { (probit-S) }\end{array}$ & $\begin{array}{l}\text { Pretax return on perperment capital; ROA; return } \\
\text { on stock; E/P; D/P; ROA veriability; pretax return } \\
\text { variability; pretax interest coverage; pretax } \\
\text { interest coverage including rent; EBITDA interest } \\
\text { coverage; cash flowTL; cash flow/LTL; free cash } \\
\text { flow/LTL; LTLTAA;STD/LTD; deferred taxes/LTD; } \\
\text { MV of TA; MV of common equity; BM; sales } \\
\text { growth in recent } 3 \text { years; Asset turnover; } \\
\text { receivable turnover; current ratio; quick ratio; } \\
\text { size of bonds; and dividend/interest. }\end{array}$ \\
\hline PACKER (2000) & Rasio keuangan & Regresi & $\begin{array}{l}\text { Retained earnings; MV of equity + net debt; } \\
\text { rasio of operating profittTA; dan utility industry. }\end{array}$ \\
\hline $\begin{array}{l}\text { KAMSTRA, } \\
\text { KENNEDY \& SUAN } \\
(2001)\end{array}$ & Rasio keuangan & $\begin{array}{l}\text { Probit; logit; MDA; } \\
\text { OLS }\end{array}$ & $\begin{array}{l}\text { Interest coverage; debt ratio; return on assets; } \\
\text { total firm asset; subordination status. }\end{array}$ \\
\hline
\end{tabular}

\section{II.3.1 Faktor-Faktor Akuntansi}

\section{II.3.1.2 Pertumbuhan (GROWTH)}

Burton et al. (1998) menyatakan bahwa pertumbuhan yang positif dalam annual surplus dapat mengindikasikan atas berbagai kondisi financial. Konsekuensinya, mereka memprediksi bahwa pemegang obligasi yang memiliki pertumbuhan yang tinggi dari tahun ke tahun dalam 
bisnis adalah lebih besar kemungkinan secara sukarela untuk kredit rating daripada insurer yang memiliki pertumbuhan yang lebih rendah. Dengan kata lain, insurer yang pengalaman growth dalam pelaporan annual surplus akan mendapat level resiko penjaminan yang lebih tinggi (Borde et al 1994; Pottier, 1997).

Bagaimanapun, studi di US sebelumnya mengenai industri asuransi (Pottier and Sommer, 1999) menemukan bukti bahwa pertumbuhan (growth) bisnis yang kuat berhubungan positif dengan keputusan rating dan grade dari rating berikutnya diberikan untuk perusahaan karena growth mengindikasikan prospek kinerja cash flow masa datang dan meningkatkan nilai ekonomi. Penelitian ini melihat growth berdasarkan kesempatan bertumbuh (growth opportunities) perusahaan yaitu menggunakan market to book value of equity ratio (Wydia, 2004). Penggunaan proksi ini ditujukan agar bisa menangkap fenomena yang sesungguhnya terhadap nilai pasar perusahaan. Berdasarkan uraian diatas maka hipotesis alternatif yang diuji dalam penelitian ini adalah:

H1: Terdapat pengaruh growth/pertumbuhan dalam memprediksi peringkat obligasi perusahaan manufaktur.

\section{II.3.1.2 Size Company (SIZE)}

Ukuran perusahaan (SIZE), merupakan salah satu variabel akuntansi yang mempengaruhi resiko obligasi (Fisher dalam Setiyono (1997)). Ukuran perusahaan dapat diukur menggunakan total assets, penjualan atau ekuitas. Jika jumlah aset, penjualan atau ekuitas tersebut besar, maka logaritma terhadap jumlah tersebut digunakan untuk tujuan penelitian (Miswanto dan Husnan (1999)).

Menurut Elton dan Gruber (1995), perusahaan-perusahaan besar kurang beresiko dibandingkan perusahaan-perusahaan kecil. Dengan kata lain, perusahaan kecil memiliki resiko lebih besar dibandingkan dengan perusahaan besar. Juga, semakin besar perusahaan, potensi mendiversifikasikan resiko non systematic-nya semakin besar, sehingga membuat resiko obligasi perusahaan tersebut menurun (Bagnani et al. (1996) dalam Maylia (2004).

Ogden (1987) dalam Lusi (2000) berpendapat bahwa karena total utang dan ukuran perusahaan mempunyai korelasi yang kuat dan positif, ukuran perusahaan juga bisa digunakan sebagai proksi untuk mengukur likuiditas. Disamping itu ukuran perusahaan juga bisa mempunyai korelasi terhadap tingkat resiko kebangkrutan atau kegagalan, sehingga disimpulkan bahwa ukuran perusahaan bisa mempunyai pengaruh terhadap rating obligasi. 
Brister et al (1994) mengatakan bahwa marketabilitas obligasi bisa dilihat berdasarkan derajat akses emiten di pasar keuangan dunia. Banyak peneliti yang beranggapan bahwa derajat akses adalah fungsi dari ukuran perusahaan atau ukuran besarnya nilai obligasi yang diterbitkan. Untuk menguji marketabilitas obligasi digunakan variabel total asset pada saat mengemisi obligasi.

H2: Terdapat pengaruh size dalam memprediksi peringkat obligasi perusahaan manufaktur.

\section{II.3.2 Faktor-Faktor Non Akuntansi}

Faktor- faktor non akuntansi yang turut dipertimbangkan adalah keterangan tentang obligasi yang terdapat dalam prospektus. Keterangan tersebut antara lain : ada tidaknya dana penyisihan pembayaran obligasi (sinking fund), dijamin tidaknya penerbitan obligasi (secure), jangka waktu jatuh tempo instrumen obligasi (maturity) (Maylia, 2004).

\section{II.3.2.1 Sinking Fund (SINK)}

Sinking fund adalah penyisihan sejumlah dana oleh emiten secara teratur untuk melunasi obligasi atau utang jangka panjangnya. Sinking fund didesain untuk melindungi investor dengan memastikan bahwa emiten memperhatikan kepentingan para pemodal. Boardman dan McEnally (1981) dalam Foster (1986) membuat model penelitian untuk menguji faktor penentu harga dan return obligasi pada tiap kategori rating secara time series. la menggunakan salah satu variabel independen yaitu ada tidaknya sinking fund pada penerbitan obligasi. Hasilnya menyatakan bahwa obligasi berkualitas rendah (tidak menyediakan sinking fund) harga dan returnnya kurang homogen dibanding yang berkualitas tinggi. Dalam hal ini bila terdapat sinking fund maka peringkat obligasi akan semakin tinggi. Obligasi yang memberikan penyisihan dana atau memberi ketetapan sinking fund pada saat mengemisi dipandang relatif lebih aman dibanding obligasi tanpa adanya sinking fund.

Disamping itu menurut Wu (1993) manfaat lain dari sinking fund adalah tingkat amortisasi sinking fund tersebut memberkan sinyal kualitas kredit perusahaan.

H3: Terdapat pengaruh sinking fund dalam memprediksi peringkat obligasi perusahaan manufaktur.

\section{II.3.2.2 Risk}

Tingkat resiko yang terkandung dalam sebuah obligasi dipengaruhi oleh jaminan. Berdasarkan jaminan tersebut, obligasi dibedakan atas obligasi yang dijamin dan tidak dijamin. Debenture atau unsecured bond adalah suatu obligasi yang tidak dijamin dengan kekayaan 
tertentu tetapi dijamin dengan kekayaan penerbitnya secara umum. Brister et.al (1994) mengatakan bahwa secara umum investor akan lebih menyukai yang aman dibanding debenture. Variabel resiko yang tergantung pada jaminan ini diwakili oleh variabel secure dalam model logif yang dipergunakan.

Realisasi klaim default, bagaimanapun tergantung atas senioritas dari klaim dan nilai asset perusahaan. Atas default, asset perusahaan atau nilai going concern didistribusikan untuk kreditur didasarkan pada prioritas dari klaim mereka. Middle market dan perusahaan non-investmen grade dengan basis aset berwujud yang kuat, tetapi rendah volatilitas aliran cashflow-nya, maka sering menggunakan pendekatan ini. Peminjam (lender) menggunakan aset paling likuid sebagai sumber pembayaran utama dan bunga sekuritas dalam asset financed (Joseph, 2002).

Sedangkan tipe corporate bond yang mempunyai klaim umum atas aset bisnis dari perusahaan, aset penjamin obligasi memegang prioritas klaim yang paling tinggi, atas aset spesifik dari penerbit. Status prioritas penjamin diterima melalui strukturisasi atas trust yang menjadi pemiliki legal dari aset. Trust ini dibentuk untuk kebangkrutan yang berarti aset yang menjamin obligasi tidak terpengaruh jika penerbit menghadapi masalah kredit. Apabila obligasi dijamin dengan aset yang bernilai tinggi, maka rating pun akan membaik.

H4: Terdapat pengaruh antara asset yang dijaminkan dalam memprediksi peringkat obligasi perusahaan manufaktur.

\section{II.3.2.3 Umur Obligasi (MATURITY).}

Mark dan David (1996) melakukan pengujian secara empiris mengenai penentuan struktur debt maturity menggunakan pengukuran struktur maturity mengenai informasi detail secara keseluruhan utang perusahaan. Mereka menemukan dukungan yang kuat untuk prediksi atas hubungan signifikan antara debt maturity dan bond rating; perusahaan yang rating obligasinya tinggi menggunakan term debt yang lebih pendek sedangkan perusahaan lain menggunakan term debt yang lebih lama.Diamond's (1991), menemukan bukti yang kuat dari hubungan nonmonotonik antara struktur debt maturity dan kualitas kredit untuk perusahaan yang tercantum dalam debt rating.

Berdasarkan penelitian sebelumnya, obligasi dengan umur yang lebih pendek mempunyai resiko yang lebih kecil. Oleh karena itu akan dilakukan pengujian apakah umur obligasi yang lebih rendah memiliki peringkat yang lebih baik dibanding obligasi yang memiliki umur obligasi yang lebih panjang.

H5: Terdapat pengaruh debt maturity dalam memprediksi peringkat obligasi perusahaan manufaktur. 


\section{II.3.2.4 Auditor}

Penelitian-penelitian yang menggunakan variabel reputasi auditor dan underwriter adalah penelitian-penelitian yang berkaitan dengan Initial Public Offering dan underpricing, seperti yang telah dilakukan Trisnawati (1998), Nasirwan (1999), Hidayati (2002), dan Setyanongrum (2002) dalam Luciana (2003).

Allen (1994) melakukan pengujian mengenai persepsi agen pemeringkat atas manfaat informasi akuntansi yang dinilai dengan pengujian hubungan antara informasi akuntansi dan bond ratings. Dalam hal ini pengguna informasi keuangan merasa bahwa auditor Big 8 menyediakan kualitas audit yang lebih baik untuk perusahaan dan pemerintah daerah (municipa). Analisis empiris mendukung hipotesis bahwa audit Big 8 berhubungan dengan kemampuan informasi akuntansi untuk memprediksi secara akurat keputusan bond rating municipal. Dengan perbandingan, hasil mengindikasikan bahwa informasi akuntansi berhubungan dengan audit non-Big 8 yang tidak dapat untuk memprediksi keputusan bond rating municipal lebih baik daripada random. Emiten obligasi yang lemah namun dijamin oleh perusahaan yang kuat maka emiten akan diberi rating yang kuat .

Argumentasi yang mendasari dimasukkannya variabel reputasi penjamin emisi (underwriter) dan auditor adalah semakin tinggi reputasi mereka maka semakin tinggi pula tingkat kepastian suatu perusahaan. Dengan kata lain, semakin tinggi reputasi penjamin emisi dan auditornya maka semakin kecil kemungkinan perusahaan mengalami kegagalan. Akan tetapi peneliti hanya mengambil variabel auditor saja.

H6: Terdapat pengaruh auditor dalam memprediksi peringkat obligasi perusahaan manufaktur.

\section{METODA PENELITIAN}

\section{III.1 Sumber Data, Populasi dan Sampel}

Data yang digunakan dalam penelitian ini adalah data sekunder yang diperoleh dari database Magister Manajemen UGM, database Bursa Efek Jakarta (http://www.jsx.co.id), database Bursa Efek Surabaya (http://www.ssx.co.id), data dari Indonesia Capital Market Directory; dan juga database rating obligasi perusahaan yang dikeluarkan PEFINDO (www.pefindo.com). Sampel dipilih dengan menggunakan metode purposive sampling. Perusahaan yang dijadikan sampel berjumlah 36 perusahaan yang masing-masing menerbitkan obligasi berturut-turut tiga tahun sehingga jumlah observasi adalah 108. Adapun kriteria yang lain adalah sebagai berikut: 
Perusahaan manufaktur yang terdaftar di BEJ dan BES serta terdaftar dalam rating obligasi yang dikeluarkan PEFINDO mulai tahun 2000-2002. Tabel V.3.1 menyajikan prosedur pemilihan sampel

Tabel V.3.1

Prosedur Pemilihan Sampel

Obligasi perusahaan yang terdaftar di PEFINDO tahun 1995-2002

456

Obligasi perusahaan yang termasuk sektor perbankan dan keuangan

$(\underline{162})$

294

Obligasi perusahaan yang termasuk sektor non-keuangan dan perbankan 162

Tidak memiliki laporan keuangan lengkap tahun 2000-2002

$\underline{24}$

Tidak memiliki data dalam rupiah

186

Obligasi perusahaan yang tidak digunakan dalam sampel

108

\section{III.2 Penelitian dan Pengukuran Variabel}

\section{III.2.1 Variabel Dependen}

Variabel ini mengukur tingkat peringkat obligasi perusahaan dengan memberi nilai pada masing-masing ratings yang mengacu pada kategori ratings yang dikeluarkan oleh PEFINDO. Kategori secara umum terbagi dua : investment (AAA, AA, A, BBB) dan non investment (BB, B, CCC, D).

\section{III.2.2 Variabel Independen}

Variabel bebas yang hendak diuji dalam penelitian ini salah satunya adalah rasio keuangan yang pernah diuji oleh beberapa peneliti terdahulu dan disesuaikan dengan data yang tersedia, yaitu diambil dari laporan keuangan yang dipublikasikan. Penelitian ini menggunakan beberapa data non akuntansi yaitu indenture provision (sinking fund, asset penjamin obligasi), debt maturity dan underwriter (auditor).

\section{III.3 Pengujian Hipotesis}

Pengujian hipotesis dalam penelitian ini menggunakan regresi logit, karena variabel dependennya berupa variabel dummy (Gujarati, 1995: 554). Adapun modelnya adalah sebagai berikut : 


\section{$R A T I N G=\beta O+\beta 1$ GROWTH $+\beta 2$ SIZE $+\beta 3$ SINK $+\beta 4$ SECURE $+\beta 5$ MATURITY $+\beta 6$ AUDITOR+ eit}

\section{Keterangan:}

Bo $\quad$ : intercept

Rating : peringkat obligasi.

Growth : tingkat pertumbuhan yang diukur menggunakan Book to Market Ratio (Book Value of Common Equity/Market Value of Common Equity)

Size : : log total asset saat emisi obligasi $i$, yang diterbitkan.

Sink : variabel kategorikal, 1 jika obligasi itu punya ketetapan sinking fund, dan 0 jika obligasi tidak punya ketetapan sinking fund.

Secure : variabel kategorikal, 1 jika obligasi dijamin dengan asset khusus, 0 jika obligasi berupa surat hutang saja yang tidak dijamin dengan asset khusus.

Maturity : variabel kategorikal, 1 jika obligasi mempunyai umur kurang dari lima tahun, 0 jika obligasi mempunyai umur lebih dari lima tahun.

Auditor : variabel kategorikal, 1 jika obligasi diaudit oleh the big 4, 0 jika obligasi diaudit oleh selain the big 4. Adapun anggota big 4 adalah

1. Prasetio Utomo \& Co affiliated with Andersen

2. Hadi Sutomo \& Rekan affiliated with Pricewaterhousecoopers

3. Hanadi Sarwoko \& Sandjaya affiliated with Ernst \& Young

4. Hans Tuanakota \& Mustafa Affiliated wuth Deloite Touce \& Tomatsu

eit

: error term

\section{ANALISIS DATA DAN HASIL PENELITIAN}

\section{IV.1 Hasil Pengujian}

\section{IV.1.2 Hasil Pengujian Hipotesis 1 sampai Hipotesis 6}

Pengujian hipotesis dilakukan dengan menggunakan regresi logistik berganda dengan empat variabel independen. Hasil dari pengujian regresi logistik berganda dengan tingkat signifikansi yang digunakan adalah 0,05. Hasil pengujian regresi logistik secara ringkas dapat dilihat pada Tabel V.4.1 berikut

Nilai Hosmer and Lemeshaw test sebesar 0.201 dan nilai probabilitas Chi- Square sebesar 11.010 yang lebih besar dari tingkat signifikansi 0.05 , menunjukkan bahwa model ini sudah cukup baik, artinya tidak ditemukan adanya perbedaan yang nyata antara klasifikasi yang diprediksi dengan yang diamati dan model regresi binary ini layak dipakai untuk analisis 
Tabel V.4.1

Hasil Uji Hipotesis 1 sampai 4 Model Analisis Regresi Logistik Dua Kategori

Persamaan Regresi Logistik

$Y=-1.046+0.702$ GROWTH +0.000 SIZE -1.432 SINK + 0.591 SECURE

-1.394 MATURITY + 1.871 AUDITOR

\begin{tabular}{|c|c|c|c|c|c|}
\hline Variabel & B & S.E & Wald & Df & Sig \\
\hline GROWTH & 0.702 & 0.299 & 5.509 & 1 & $0.019 *$ \\
\hline SIZE & 0.000 & 0.000 & 0.076 & 1 & 0.783 \\
\hline SINK & -1.432 & 0.686 & 4.361 & 1 & $0.037 *$ \\
\hline SECURE & 0.591 & 0.864 & 0.864 & 1 & 0.494 \\
\hline MATURITY & -1.394 & 0.643 & 4.707 & 1 & $0.030 *$ \\
\hline AUDITOR & 1.871 & 0.701 & 7.125 & 1 & $0.008^{*}$ \\
\hline Constan & -1.046 & 0.996 & 1.103 & 1 & 0.294 \\
\hline \multicolumn{3}{|l|}{$N$} & \multicolumn{3}{|l|}{108} \\
\hline \multicolumn{3}{|c|}{ - 2 Log Likelihood Block 0} & \multicolumn{3}{|l|}{142.381} \\
\hline \multicolumn{3}{|c|}{ - 2 Log Likelihood Block 1} & \multicolumn{3}{|l|}{108.768} \\
\hline \multicolumn{3}{|c|}{ Hosmer and Lemeshaw Test } & \multicolumn{3}{|l|}{0.201} \\
\hline \multicolumn{3}{|l|}{ Chi-Square } & \multicolumn{3}{|l|}{11.010} \\
\hline
\end{tabular}

selanjutnya. Untuk melihat kecocokan model (model fit), kriteria yang digunakan adalah nilai 2 Log Likehood (-2 LL) adanya penurunan nilai dari 142.381 menjadi 108.768 mengindikasikan bahwa model regresi ini baik.

Hasil pengujian regresi logistik menunjukkan bahwa koefisen regresi untuk struktur kepemilikan adalah positif secara statistik signifikan pada $p<0.05$, maka dapat disimpulkan bahwa dengan tingkat keyakinan 95\% growth mempengaruhi prediksi peringkat obligasi. Dengan demikian hipotesis yang menyatakan bahwa growth mempengaruhi prediksi peringkat obligasi tidak ditolak. Dilain pihak tanda positif menunjukkan bahwa semakin besar growth atau pertumbuhan suatu perusahaan maka perusahaan tersebut akan memiliki peringkat obligasi investment grade. Hasil penelitian ini memberi dukungan untuk hipotesa satu, yakni terdapat pengaruh growth/pertumbuhan perusahaan dalam memprediksi peringkat obligasi perusahaan.

Koefisien regresi untuk size adalah positif tetapi secara statistik tidak signifikan pada $\mathrm{p}<$ 0.05, maka disimpulkan dengan tingkat signifikansi $95 \%$ size yang diproksikan dengan total asset tidak mempunyai pengaruh terhadap prediksi peringkat obligasi. Dengan demikian hipotesa yang menyatakan bahwa terdapat pengaruh size dalam memprediksi peringkat obligasi perusahaan manufaktur di tolak. Hasil ini tidak mendukung hipotesa dua, yakni tidak terdapat pengaruh size/ ukuran perusahaan dalam memprediksi peringkat obligasi perusahaan manufaktur. 
Sinking fund secara statistik signifikan pada $\mathrm{p}<0.05$, maka dapat disimpulkan dengan tingkat keyakinan 95\% sinking fund mempunyai pengaruh terhadap prediksi peringkat obligasi perusahaan. Dengan demikian hipotesis yang menyatakan bahwa sinking fund mempengaruhi prediksi peringkat obligasi tidak dapat ditolak. Hasil penelitian ini memberi dukungan untuk hipotesa tiga, yakni terdapat pengaruh sinking fund dalam memprediksi peringkat obligasi perusahaan manufaktur.

Koefisien regresi untuk secure adalah positif tetapi secara statistik tidak signifikan pada $p<0.05$, maka disimpulkan dengan tingkat signifikansi $95 \%$ secure / jaminan tidak mempunyai pengaruh terhadap prediksi peringkat obligasi. Dengan demikian hipotesa yang menyatakan bahwa terdapat pengaruh secure dalam memprediksi peringkat obligasi perusahaan manufaktur di tolak. Hasil ini tidak mendukung hipotesa empat, yakni tidak terdapat pengaruh antara asset yang dijaminkan dalam memprediksi peringkat obligasi perusahaan manufaktur.

Secara statistik maturirty / umur obligasi signifikan pada $p<0.05$, maka dengan tingkat keyakinan 95\% disimpulkan bahwa perusahaan yang umur obligasinya kurang dari 5 tahun mempunyai peringkat obligasi investment grade. Hal ini memberi dukungan terhadap hipotesa lima, yakni terdapat pengaruh debt maturity/umur obligasi dalam memprediksi peringkat obligasi perusahaan manufaktur.

Koefisien regresi untuk auditor adalah positif yang secara statitik signifikan pada $\mathrm{p}<$ 0.05, maka dengan tingkat keyakinan 95\% disimpulkan bahwa perusahaan yang di audit oleh kantor akuntan publik / auditor big 4 mempunyai peringkat obligasi investment grade. Dilain pihak tanda positif menyatakan bahwa makin sering perusahaan di audit oleh auditor big 4 maka perusahaan mempunyai peringkat obligasi investment grade. Hal ini memberi dukungan terhadap hipotesa enam, yakni terdapat pengaruh auditor dalam memprediksi peringkat obligasi perusahaan manufaktur.

\section{IV.3 Implikasi}

Penelitian ini menyimpulkan bahwa growth/ pertumbuhan perusahaan ternyata mempunyai pengaruh terhadap prediksi peringkat obligasi. Ini sesuai dengan penelitian yang dilakukan oleh (Pottier and Sommer, 1999) yang megenai industri asuransi di US, ditemukan bukti bahwa pertumbuhan (growth) bisnis yang kuat berhubungan positif dengan keputusan rating dan grade yang diberikan oleh pemeringkat obligasi. Pada umumnya dengan pertumbuhan perusahaan yang baik akan memberikan peringkat obligasi yang investment grade. Investor didalam memilih investasi terhadap obligasi akan melihat pengaruh growth 
atau pertumbuhan perusahaan apabila pertumbuhan perusahaan dinilai baik maka perusahaan penerbit obligasi akan memiliki peringkat obligasi invesment grade. Oleh karena itu investor disarankan untuk memilih perusahaan penerbit obligasi yang mempunyai pertumbuhan perusahaan yang baik.

Sementara dari size/ukuran perusahaan yang menggunakan proksi total assets menunjukkan bahwa walaupun total assetsnya besar tetapi masih tergolong non investment grade, ini bertentangan dengan penelitian-penelitian asing sebelumnya. Biasanya dengan total assets yang besar akan mengindikasikan peringkat investment grade, hal ini bisa terjadi dimungkinkan karena pengamatan data yang hanya tiga tahun saja. Berdasarkan penelitian ini ukuran perusahaan yang diproksikan dengan total aset dinilai tidak berpengaruh terhadap peringkat obligasi sehingga investor boleh mengabaikan ukuran perusahaan.

Sedangkan pada faktor sinking fund ternyata mempunyai pengaruh terhadap prediksi peringkat obligasi, ini sesuai dengan penelitian yang dilakukan oleh Boardman dan McEnally (1981) dalam Foster (1986) yang menyatakan jika perusahaan memberikan ketetapan sinking fund akan mempunyai peringkat obligasi yang tinggi. Pada umumnya obligasi yang diterbitkan perusahaan yang menyisihkan dana sebagai pokok pelunasan hutang obligasi akan mengindikasikan obligasi tersebut aman untuk berinvestasi. Sementara perusahaan yang memberikan sinking fund atau penyisihan sejumlah dana oleh emiten secara teratur untuk melunasi obligasi atau hutang jangka panjangnya ternyata mempengaruhi terhadap peringkat obligasi sehingga investor dianjurkan untuk melihat ada atau tidaknya sinking fund diperusahaan.

Dari segi jaminan/secure ternyata tidak mempunyai pengaruh terhadap prediksi peringkat obligasi, ini ternyata bertentangan penelitian yang dilakukan oleh Brister et al (1994) yang menyatakan investor akan menyukai yang aman dibanding unsecured bond dan Joseph (2002) yang menyatakan asset yang dijaminkan, maka rating pun akan membaik. Biasanya dengan adanya aset yang dijaminkan untuk obligasi, sebenarnya mengindikasikan obligasi tersebut aman untuk di investasikan. Sedangkan secure atau jaminan yang diberikan oleh emiten ternyata tidak berpengaruh terhadap tingkat obligasi. Jadi investor boleh tidak memperhatikan jaminan yang diberikan oleh perusahaan.

Umur obligasi ternyata mempunyai pengaruh terhadap prediksi peringkat obligasi, ini sejalan dengan penelitian yang dilakukan Mark dan David (1996) yang menunjukkan perusahaan yang rating obligasinya tinggi menggunakan umur obligasi yang pendek serta penelitian yang dilakukan Diamonds (1991) yang menemukan bahwa terdapat hubungan nonmonotonik antara struktur umur obligasi dan kualitas kredit untuk perusahaan yang tercantum dalam peringkat obligasi. Selain itu umur obligasi yang pendek ternyata menunjukan peringkat obligasi investment grade. Oleh sebab itu maka perusahaan dianjurkan untuk memilih perusahaan yang mempunyai 
umur obligasi kurang dari lima tahun.

Perusahaan yang di audit oleh Big 4 ternyata mempunyai pengaruh terhadap prediksi peringkat obligasi, ini juga sesuai dengan penelitian Allen (1994) yang mengindikasikan bahwa pengguna informasi keuangan merasa bahwa auditor Big 8 menyediakan kualitas audit yang lebih baik untuk perusahaan dan pemerintah daerah. Dengan reputasi auditor yang baik akan memberikan hasil audit yang dapat dipercaya. Sementara emiten yang diaudit oleh auditor big 4 akan mempunyai obligasi yang invesment grade. Berarti investor haruslah melihat apakah perusahaan diaudit oleh big 4 atau tidak, jika diaudit oleh big 4 disarankan untuk memilih menginvestasikan dana terhadap obligasi tersebut.

\section{KESIMPULAN, KETERBATASAN DAN PENELITIAN BERIKUTNYA}

\section{V.1 Kesimpulan}

Penelitian ini merupakan penelitian yang pertama untuk melihat faktor-faktor yang mempengaruhi prediksi peringkat obligasi dengan membagi faktor akuntansi dan faktor non akuntansi. Penelitian ini berusaha menjawab pertanyaan tentang faktor-faktor apa saja yang bisa mempengaruhi prediksi peringkat obligasi pada perusahaan-perusahaan manufaktur di Indonesia.

Teori sinyal mengemukakan tentang bagaimana seharusnya sebuah perusahaan memberikan sinyal-sinyal pada pengguna laporan keuangan. Informasi yang berupa pemberian peringkat obligasi perusahaan yang dipublikasikan diharapkan dapat menjadi sinyal kondisi keuangan perusahaan tertentu dan menggambarkan kemungkinan yang terjadi terkait dengan hutang yang dimiliki. Di dalam penelitian ini variabel dependen dilihat berdasarkan peringkat yang dikeluarkan oleh PEFINDO, yang diperkirakan akan dipengaruhi oleh faktor akuntansi berupa growth dan size sedangkan faktor non akuntansi berupa sinking fund, secure, maturity, auditor.

Penelitian ini menggunakan variabel dependen dengan kategori (1) untuk investment grade dan (0) untuk non investment grade. Sedangkan variabel independennya growth, size,sinking fund, secure, maturity dan auditor. Sampel yang digunakan sebanyak 108 obligasi perusahaan manufaktur pada tahun 2000 sampai 2002.

Hasil penelitian menunjukkan dukungan terhadap hipotesa 1 yang menyatakan bahwa growth/pertumbuhan perusahaan mempengaruhi prediksi peringkat obligasi. Pengujian yang menyatakan bahwa size/ukuran perusahaan mempengaruhi prediksi peringkat obligasi ditolak. Peneliti menduga penolakan terhadap hipotesa 2 disebabkan oleh size / ukuran perusahaan yang diproksikan dengan total asset tidak dapat menentukan peringkat obligasi perusahaan, 
karena pada umumnya untuk melihat peringkat obligasi yang dilihat dari segi kewajiban / hutang perusahaan, selain itu peringkat obligasi terkait dengan kemampuan perusahaan melunasi kewajibannya / hutang. Jadi seberapapun besarnya total asset suatu perusahaan tidak akn mempengaruhi peringkat obligasi. Hasil penelitian ini menolak pernyataan Fisher dalam Setiyono (1997) yang menyatakan ukuran perusahaan merupakan salah satu variabel akuntansi yang mempengaruhi resiko obligasi.

Sinking fund juga akan mempengaruhi prediksi peringkat obligasi. Dapat disimpulkan bahwa perusahaan yang memiliki sinking fund akan mempengaruhi prediksi peringkat obhligasi. Hasil ini juga konsisten dengan penelitian Boardman dan McEnally (1981) dalam Foster (1986). Hal ini menunjukkan dukungan terhadap hipotesa 3. Hasil pengujian yang menyatakan bahwa secure/jaminan mempengaruhi prediski peringkat obligasi ditolak. Peneliti menduga penolakan terhadap hipotesa ini diduga bahwa obligasi yang dijamin atau tidak dijamin tidak akan mempengaruhi prediksi peringkat obligasi, karena dilihat dari catatan laporan keuangan walaupun perusahaan itu tidak mempunyai jaminan tetapi peringkat yang dikeluarkan oleh PEFINDO tetap berada pada investment grade.

Maturity / umur obligasi mempengaruhi prediski peringkat obligasi. Dapat disimpulkan bahwa perusahaan yang memiliki umur obligasi kurang dari 5 tahun akan berada pada peringkat obligasi investment grade, dan jelas akan mempengaruhi prediski peringkat obligasi. Hasil penelitian ini sesuai dengan pernyataan Diamonds (1991) yang menemukan bahwa terdapat hubungan nonmonotonik antara struktur umur obligasi dan kualitas kredit untuk perusahaan yang tercantum dalam peringkat obligasi. Hasil ini memberi dukungan terhadap hipotesa 5. Perusahaan yang diaudit oleh big 4 akan mempunyai peringkat obligasi investment grade. Sehingga auditor akan mempengaruhi prediksi peringkat obligasi. Hasil penelitian ini sesuai dengan pernyataan Allen (1994) dengan menguji hubungan antara auditor big 8 dengan peringkat obligasi. Hasil ini memberi dukungan terhadap hipotesa 6.

\section{V.2 Keterbatasan}

Salah satu kelemahan penelitian ini adalah penggunaan sampel yang tidak dilakukan dengan acak tetapi dengan penyampelan bersasaran (purposive sampling) yang hanya dibatasi pada perusahaan manufaktur saja, sehingga temuan ini tidak dapat digeneralisasi. Idealnya untuk mengetahui peringkat obligasi perusahaan-perusahaan manufaktur di Indonesia harus menggunakan keseluruhan perusahaan yang terdaftar di Bursa Efek Jakarta sehingga hasilnya lebih komprehensif. 


\section{V.3 Penelitian Berikutnya}

Penelitian ini membuktikan bahwa growth, sinking fund, maturity dan auditor mempengaruhi prediksi preringkat obligasi. Terdapat dua variabel yaitu size yang diproksikan dengan total asset, dan secure/ jaminan. Penelitian berikutnya dapat menggunakan proksi size yang lain seperti log of net sales. Penelitian ini hanya melihat enam faktor saja, sebagai faktor non akuntansi yang mempengaruhi prediksi peringkat obligasi. Penelitian berikutnya bisa menambahkan faktor-faktor non akuntansi lain.

Penelitian berikutnya perlu mempertimbangkan sampel yang lebih representatif dan diseleksi secara random, serta waktu pengamatan yang lebih lama kemungkinan memberikan hasil yang lebih baik. 


\section{DAFTAR PUSTAKA}

Allen, Arthur C. 1994. "The effect of large-firm audits on municipal bond rating decisions". A Journal of Practice \& Theory (APT), Vol. 13, Spring.

Altman, Edward I. 1968. "Financial ratio, Discriminant analysis and the prediction of corporate bankruptcy". The Journal of Finance, pp 589-609.

Beaver, William H. 1966. "Financial ratio as predictors of failure". Journal of Accounting Research, p. 71-111.

Brister, et. al. 1994. "The regulation effect of bond rating on yield". Journal of Finance, pp. 510-531.

Borde, S.F; K. Chambliss and J. Madura. 1994. "Explaining variation in Risk Across insurance companies". Journal of Financial Service Research. Vol 8, September: 177-191.

Bursa Efek Surabaya. 2001. "Mengenal Obligasi". Over The Counter Fix Income Service.

Burton, B; Mike, A; and Hardwick, P. 1998. " The determinants of credit ratings in United Kingdom insurance industry", download www.google.com.

Chan, K; Jagadeesh, N; and warga, A. 1999. " Market based evaluation for model to predict bond ratings and corporate bond trading strategy", download www.google.com.

Deakin, E.B. 1972. "A Discriminant Analysis of Predictors of Business Failure, Journal of Accounting Research, March.

Diamond, D.W. 1991. "Debt maturity structure and liquidity risk. Quarterly Journal of Economics 106, August.

Elton, Edwin, J and Martin J. Gruber. 1995. "Modern Portfolio Theory and Investment Analysis, Fifth Edition, John Willey \& Sons, Inc., New York.

Foster, George. 1986. "Financial Statement Analysis. Prentice Hall International, Inc.

Gujarati, D.N., "Basic Econometric third edition, Mc Graw_Hill, Inc

Horrigan, J. 1966. "The determination of long term credit standing with financial ratios, empirical research in accounting : Selected Studies". Supplement to Journal of Accounting Research.

Hoven, Mark. S; Mauer, David. C. 1996. "The determinants of corporate debt maturity structure". Journal of Business, Vol. 69, No. 3). 
Kaplan. R.S, and G. Urwitz. 1979. "Statistical models of bond rating: A Methodological Inquiry". The Journal of Business, April.

Kesumawati, Lusi. 2000. "Pengaruh peringkat utang dan berbagai faktor yang turut mempengaruhi harga obligasi sebagai variabel kontrol terhadap yield Premium obligasi. Thesis S-2, Pascarsarjana, UGM.

Machfoedz, Mas'ud. 1994. "Financial ratio analysis and the prediction of earnings changes in Indonesia". KELOLA, No. 7/ III, p. 114-137.

Maylia, Pramono Sari, 2004. " Ketepatan peringkat obligasi antara agen dan peneliti, Tesis S2. UGM, Jogjakarta

Miswanto, and Suad Husnan. 1999. "The effect of operating leverage, cyclicality, and firm size on business risk, Gadjah Mada International Journal of Business, Vol. I, No.1.

Nurhasanah, 2003. "Kemampuan rasio keuangan dalam memprediksi peringkat obligasi perusahaan manufaktur : Analisis Diskriminan dan Regresi Logistik". Thesis S-2, Pascasarjana, UGM.

Pinches, G. F. and K. A. Mingo. 1975. "The role of subordination and industrial bond ratings". The Journal of Finance, March.

PEFINDO. 2002. "Indonesian Rating Highlight". Pefindo Credit Rating, August.

Pottier, S.W; and D.W. Sommer. 1997. "Agency theory and life insurer ownership structure". The Journal of Risk and Insurance. Vol. 64, December: 529-545.

1999. "Property-liability insurer financial strength ratings: Difference Across Rating Agencies". The Journal of Risk and Insurance, Vol. 66, December.

Rizzi, Joseph. V. 2002. "Determining debt capacity". Commercial Lending Review.

Setiyono. 1997. "Analisis dampak struktur kepemilikan saham manajerial pada penilaian obligasi perusahaan. Tesis S-2, Pascasarjana, UGM.

Spica. A, Luciana. 2003. "Analisis faktor-faktor yang mempengaruhi kondisi financial distress suatu perusahaan yang terdaftar di Bursa Efek Jakarta". SNA VI.

Warsono. 1997. "Prospek emisi obligasi di Indonesia". Usahawan, No. 9, Th. XXVI, September.

Wu, Chunchi. 1993. "Information asymmetry and the sinking fund provision". Journal of Financial and Quantitative Analysis, Vol. 28, No. 3.

Wydia. 2004. Faktor-faktor yang mempengaruhi pilihan perusahaan terhadap akuntansi konservatif, Tesis S2. UGM. Jogjakarta. 